УДК 376.1-056.264:373.2

DOI https://doi.org/10.32782/apv/2021.4.22

\title{
Ірина БРУШНЕВСЬКА
}

кандидат педагогічних наук, доцент кафедри спеціальної та інклюзивної освіти, Волинський національний університет імені Лесі Украӥнки, просп. Волі, 13, м. Луцьк, Волинська область, Украӥна, 43025

ORCID: 0000-0002-3381-6490

Бібліографічний опис статті: Брушневська, I. (2021). Методичні засади розвитку зв'язного мовлення дітей дошкільного віку із порушеннями психофізичного розвитку. Acta Paedagogica Volynienses, 4, 145-150, doi: https://doi.org/10.32782/apv/2021.4.22

\section{МЕТОДИЧНІ ЗАСАДИ РОЗВИТКУ ЗВ'ЯЗНОГО МОВЛЕННЯ ДІТЕЙ ДОШКІЛЬНОГО ВІКУ ІЗ ПОРУШЕННЯМИ ПСИХОФІЗИЧНОГО РОЗВИТКУ}

Метою статті є аналіз та обтрунтування ефективності використання сучасних нетрадиційних методів i прийомів роботи у корекційній роботі із розвитку зв'язного мовлення дітей дошкільного віку із порушеннями психофізичного розвитку. Основний акиент зроблено на доцільності застосування ейдотехніки. Ейдетика - ие особливий різновид образної пам'яті, здатність найбільш яскраво й точно відтворювати в усіх деталях наочні образи предметів, які в даний момент не діють на органи чуттів. Розглянуто основні засади становлення явищза ейдетизму як у психологічній, так і у педагогічних науках. Сьогодні ия ігрова методика популярна серед тих, хто прагне творчо ставитися до проиесів пізнання та навчання. Особливої актуальності ияя теорія набуває стосовно навчання дітей, які мають певні мовленнєві вади, щуо зумовлюють серйозні утруднення в опануванні основних програмових завдань. Це наочна уява про звук, яка є зразком для наслідування у вимові. Орієнтуючись на запропоновані символи, діти запам'ятовують не лише сам звук, а й образ, щзо виникає в їхній уяві, коли вони вимовляють ией звук. Проаналізовано особливості використання у процесі розвитку зв'язного мовлення дітей

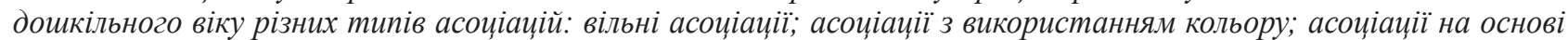
сприйняття форми; асоціації з використанням тактильних табличок; предметні асоиіаџіï; звукові асоціацїі; смакові та нюхові асоціації; використання друдлів. Використання методів ейдетики під час ігор-занять з дітьми з особливими освітніми потребами дасть можливість компенсувати недоліки у розвитку вищих психічних функцій, сприятиме корекиії відчуттів і повноцінному розвитку мовленнєвої особистості.

Ключові слова: діти дошкільного віку, порушення психофізичного розвитку, ейдетика, зв'язне мовлення, методи, прийоми.

\section{Iryna BRUSHNEVSKA}

Candidate of Pedagogical Sciences, Senior Lecturer at the Department of Special and Inclusive Education, Lesya Ukrainka Volyn National University, Volya Avenue, 13, Lutsk, Ukraine, 43025

ORCID: 0000-0002-3381-6490

\section{METHODOLOGICAL FOUNDATIONS FOR THE DEVELOPMENT OF COHERENT SPEECH IN PRESCHOOL CHILDREN WITH PSYCHOPHYSICAL DEVELOPMENTAL DISORDERS}

To cite this article: Brushnevska, I. (2021). Metodychni zasady rozvytku zviaznoho movlennia ditei doshkilnoho viku iz porushenniamy psykhofizychnoho rozvytku [Methodological foundations for the development of coherent speech in preschool children with psychophysical developmental disorders]. Acta Paedagogica Volynienses, 4, 145-150, doi: https://doi.org/10.32782/apv/2021.4.22

The purpose of the article is to analyze and substantiate the effectiveness of the use of modern non-traditional methods and techniques of work in correctional work on the development of coherent speech in preschool children with impaired psychophysical development. The main emphasis is placed on the feasibility of using eidotechnics. Eidetic is a special kind of figurative memory, the ability to most vividly and accurately reproduce in all details the visual images of objects that now do not affect the senses. The main principles of the formation of the phenomenon of eidetism are considered both in the psychological and later in the pedagogical sciences. Today, this game technique is popular among those who seek to be creative in the processes of knowledge and learning. This theory acquires particular relevance for teaching children who have certain speech deficiencies, which cause serious difficulties in mastering the main program tasks. It is a visual representation of sound, which is a role model in pronunciation. Focusing on the proposed symbols, children remember 
not only the sound itself, but also the image that arises in their imagination when they say this sound. The features of using different types of associations in the process of developing coherent speech of preschool children are analyzed: free associations; associations using color; associations based on perception of form; associations with the use of tactile plates; subject associations; sound associations; taste and olfactory associations; use of Drudl. The use of eidetic methods during games-classes with children with special educational needs will compensate for the deficiencies in the development of higher mental functions, contribute to the correction of sensations and the full development of the speech personality.

Key words: preschool children, disorders of psychophysical development, eidetic, coherent speech, methods, techniques.

Актуальність проблеми. Особливої актуальності у процесі розвитку дітей дошкільного віку із порушеннями психофізичного розвитку набула проблема формування творчої самостійної мовної діяльності. Це цілком закономірна соціальна потреба, оскільки суспільству необхідна інтелектуальна, компетентна особистість, здатна критично мислити, творчо діяти, застосовувати набуті знання в нестандартних ситуаціях, неординарно розв'язувати проблеми чи створювати щось нове.

Що ми маємо сьогодні? Мовленнєві заняття 3 шаблонними, трафаретними питаннями за змістом картинки приречені із самого початку на невдачу, оскільки стає неможливою та недоречною будь-яка ініціатива з боку дітей, оригінальність їх думок. У такому пасивному емоційному стані не слід чекати від дошкільників цікавих власних розповідей. Діти часто наслідують зразок педагога, повторюють слова й, нудьгуючи, чекають на закінчення заняття.

Як же зробити так, щоб дитина накопичувала нові знання, здобувала мовленнєвий досвід охоче, 3 радістю, без тиску й нав'язування 3 боку дорослого? Зрозуміло, що вирішення цієї проблеми потребує принципової зміни підходів до організації навчально-виховного процесу, використання розроблених науковцями i практиками освітніх технологій та методичних систем.

Позитивні результати в роботі 3 дошкільниками дає використання нетрадиційних прийомів навчання мовленню (арт-терапія, ігри з піском, кольоротерапія та інші). Це цікаві форми роботи, які змушують педагога не тупцювати на місці, а щоразу відкривати щось нове не тільки для дітей, а й для себе. Кожне заняття ми 3 малюками не проводимо, а проживаємо. Нам разом цікаво i, що головне, це дає дивовижно швидкі позитивні результати в навчанні та корекції мовлення. 3 часом ми відкрили для себе ейдетику, в якій можна поєднати всі ці напрями.
Ейдетика - це особливий різновид образної пам'яті, здатність найбільш яскраво й точно відтворювати в усіх деталях наочні образи предметів, які в даний момент не діють на органи чуттів (Матюгин, 2005). Дитина не згадує, а ніби продовжує бачити, чути, відчувати те, чого вже біля неї немає.

Аналіз останніх досліджень та публікацій. Уперше ейдетику описали Аристотель (давньогрецький учений-енциклопедист, філософ і логік, засновник класичної логіки) та Демокрит (давньогрецький філософ-матеріаліст). У перекладі з давньогрецької eidos - вид, образ, взірець. Поняття «ейдетизм» словникові джерела (Великий тлумачний словник сучасної української мови, 2004) висвітлюють як досить своєрідне явище, як «здатність окремих індивідів-ейдетиків до збереження та відтворення детального образу сприйнятих раніше предметів і сцен», «як особливий (картинний) характер пам'яті, що спирається на зорові враження, дозволяє утримувати і відтворювати надзвичайно живий образ сприйнятого раніше предмета, який за своєю наочністю та детальністю не поступається образу сприйняття».

Ейдетика - це вчення про суб'єктивні наочні образи, що вперше у 1902 році згадав у своїх працях В. Урбанич у викладі результатів роботи з паціснтами із втратами слуху. Зокрема, він звернув увагу на здатність людей, які погано чують, утримувати в пам'яті образи предметів упродовж кількох днів. Вони описували на наступний день зміст картинок настільки детально, ніби продовжували бачити ïх перед собою. В. Урбанич не пов'язував це 3 резервними можливостями пам'яті, вважаючи це патологією, оскільки спостерігав цей феномен у хворих дітей. Він назвав це явище «суб' єктивно-оптичним образом». Однак це відкриття на той час не зацікавило психологів.

У психології явище ейдетизму було відкрито й описано у 1911 році німецьким професором Еріком Йеншем. Згідно 3 його визначенням 
ейдетизм - це психічне явище, яке полягає у здатності відтворювати яскравий наочний образ через значний проміжок часу, що є різновидом образної пам'яті. Як зазначав Е. Йенш, ейдетичні образи мають полімодальну природу. Він описав зоровий, слуховий і тактильний ейдетизм. Про нюховий ейдетизм згадував уже Г. Гессе, а смаковий ейдетизм добре відомий гурманам.

Щоб краще уявити місце ейдетизму серед інших психологічних та психофізіологічних феноменів, Е. Йенш запропонував провести аналогію 3 різними відтінками оранжевого кольору, які утворюють неперервний ряд між червоним i жовтим кольорами. Подібно до цього ейдетичний образ займає проміжне положення між відчуттям і уявленням.

На думку багатьох дослідників, ейдетичні здібності мають усі люди, але проявляється це по-різному. Навіть більше, деякі вчені вважають, що ейдетизм - це закономірна стадія розвитку дитини, а пік ейдетизму припадає на 11-16 років. Вважається, що у дорослих він менш виражений, i лише у небагатьох ця здатність зберігається на все життя. Ейдетичні здібності помічали у себе деякі вчені, художники і письменники: Й. Гете, Д. Лондон, В. Вундт, Е. Мах, а також А. Білий, Б. Пильняк, О. Толстой, К. Федін, О. Форш та інші. Так, К. Федін писав: «Я спочатку чую те, що пишу», а О. Толстой говорив про свої образи: «Я їх фізично бачив». А. Ейнштейн міг образно «бачити» силу струму, напругу та інші абстрактні фізичні величини. Коли його запитували, як він прийшов до відкриття теорії відносності, він розповідав, що уявляв себе частинкою, що мчить зі швидкістю світла, спостерігаючи, як у цьому стані виглядає Земля і все, що з нею відбувається.

Мета дослідження - аналіз та обгрунтування особливостей застосування методів та прийомів ейдетики у розвитку зв'язного мовлення дітей із порушеннями психофізичного розвитку.

Виклад основного матеріалу дослідження. У середині 80 -х років XX ст. російський учений Ігор Матюгін розробив ігрову систему, яка покращує сприймання та відтворює інформацію, спираючись на властиве кожній людині вміння уявляти та фантазувати. Він запропонував використовувати весь спектр уявлень і фантазій: зорових, рухових, тактильних, нюхових та смакових. Методика отримала назву Школа ейдетики. В Україні їх продовжувачами стала Українська школа ейдетики Свгена Антощука (Антощук, 2015). Сьогодні ця ігрова методика популярна серед тих, хто прагне творчо ставитися до процесів пізнання та навчання. Завдяки розвиткові образної уяви та яскравої фантазії ейдетика допомагає використовувати ті виняткові можливості, «резерви», які є у кожного з нас.

За допомогою яскравої дитячої уяви можна швидко і надовго запам'ятати потрібну інформацію. А головне - таке навчання, що грунтується на грі та фантазії, зовсім не обтяжує дитину. Діти на таких заняттях надовго запам'ятовують по 20-25 різнопланових слів і пригадують їх за потреби у тій же послідовності через кілька днів (Пащенко, 2008).

Особливої актуальності ця теорія набуває стосовно навчання дітей, які мають певні мовленнєві вади, що зумовлюють серйозні утруднення в опануванні основних програмових завдань. У логопедичній роботі з дітьми допомагає символізація звуків і понять. Символ це певний знак, емблема, що умовно позначає якесь поняття, щось абстрактне. Це наочна уява про звук, яка $є$ зразком для наслідування у вимові. Орієнтуючись на запропоновані символи, діти запам'ятовують не лише сам звук, а й образ, що виникає в їхній уяві, коли вони вимовляють цей звук.

Щоразу до нас на корекційні заняття приходить братик Язичок, 3 яким виконуються артикуляційні вправи (дидактичний посібник «Будиночок для Язичка»), разом шукаємо його місце у роті під час вимови певного звука. Далі знайомимось із самим звуком, оперуючи позначками-символами. Поклавши уявний звук на долоню, ми його смакуємо, описуючи, який він на смак. Причому для кожної дитини він має свій смак - відразу виникає асоціація з певним продуктом. Потім, заплющивши очі, малеча нюхає цей звук - виникає асоціація з певним місцем або подією. Уявивши себе художниками, діти малюють в уяві образ цього звука, асоціюючи його 3 певним кольором. На деяких заняттях використовую прийом «Відшукай графічний символ звука на малюнку». I нарешті - «Тактильний будиночок» (авторський посібник), де шукаємо, у якій же з кімнат живе звук. Причому в будиночку є два поверхи і горище. Звуки зазвичай живуть на певному поверсі відповідно 
до місця утворення. У кінці заняття пропоную виставити усі знайдені символи на дошку.

Спеціальні дослідження доводять, що навчання 3 використанням цих прийомів має розвивальний характер. Дитина не може забути цей звук, він стає для неї рідним. Щоразу за потреби його вимови в уяві виникає ця історія знайомства.

До того ж символізація наочного матеріалу допомагає нам швидко i надовго запам'ятовувати слова, у яких живе цей звук, заучувати напам'ять вірші. Символи використовують на всіх етапах корекційної роботи. Це дає можливість активізувати всі види аналізаторів, що сприяє ефективності роботи. Такий підхід до постановки, автоматизації та диференціації звуків має велике значення, а саме:

- легко навчає артикуляційної гімнастики («Будиночок для братика Язичка»);

- ефективно розвиває фонематичний слух (добірка аудіозаписів);

- наочно формує поняття «звук» (братик Язичок, розповіді про нього);

- зрозуміло пояснює артикуляційну позицію звука (графічні символи);

- процес автоматизації звука проходить швидко і цікаво (складання зв'язних розповідей за ілюстраціями);

- знімається потреба в самостійному етапі диференціації, який після автоматизації звука завжди був тривалим; знайомить $з$ графічним символом звука (буквою);

- розвиває творче зв'язне мовлення дітей.

Використання методів ейдетики під час ігорзанять 3 дітьми $з$ особливими освітніми потребами дасть можливість компенсувати недоліки у розвитку вищих психічних функцій, сприятиме корекції відчуттів і повноцінному розвитку мовленнєвої особистості. Використання ейдетичних прийомів під час мовленнєвих ігорзанять дає можливість дітям краще і швидше запам'ятовувати матеріал, спонукатиме їх до всебічного розвитку. В роботі доцільно застосовувати:

- вільні асоціації;

- асоціації з використанням кольору;

- асоціації на основі сприйняття форми;

- асоціації 3 використанням тактильних табличок;

- предметні асоціації;

- звукові асоціації;
- смакові та нюхові асоціації;

- використання друдлів (Антощук, 2007).

1. Вільні асоціації. Ігри за вільними асоціаціями пов'язані з предметними образами. Із самої назви «вільні асоціації» зрозуміло, що під час ігор-занять не можна використовувати жодних предметних зображень. Та в маленьких дітей ще недостатньо сформовані уявлення про навколишній світ, замало життевого досвіду, щоб будувати асоціативні зв'язки самостійно. Тому на першому етапі роботи малюкові потрібна допомога дорослого. Починати можна так:

Педагог: В мене $є$ жабка. Про що ви подумали?

Для зацікавлення дітей може використовуватися наочний посібник «Дерево думки»: дерев'яне настінне зображення розлогого дерева 3 прорізами в різні сторони (Брушневська, 2014). По цим прорізам легко рухаються кілька метеликів - символи вільної думки дитини:

- Я подумала про комарика, тому що жабка любить їсти комариків.

- Я подумала про травичку, тому що вона зелена, як жабка.

- Я подумала про вечір, тому що жабок найбільше чути увечері.

На цьому етапі проведення ігор-занять головне, щоб діти вчилися обгрунтовувати свій асоціативний вибір.

2. Колірні асоціації. Для цього виду роботи потрібні картки різних кольорів та не кольорові (чорно-білі) зображення предметів або явищ. Педагог дає дитині або ж показує усій групі картинку певного кольору. Завдання кожного - вибрати серед картинок різних предметів саме ту, зображення якої в нього асоціюється 3 заданим кольором. Дитина обгрунтовує свою відповідь.

\section{Наприклад:}

Ось зелений колір. Про що ви подумали?

- Я подумав про машину, тому щзо вона вільно їде на зелене світло.

- Я подумала про траву, тому що вона зелена.

- Я подумала про зайчика; він гризе зелену kanycmy.

Можна змінити хід гри: навпаки, пропонувати ряд предметних зображень і запитувати: «Про який колір ви подумали? Чому?» 


\section{3. Асоціації на основі сприйняття форми.} Для цього виду роботи доцільно використати картинки із зображеннями геометричних фігур та різноманітних предметів. Запитання ставити аналогічно: «У мене $\epsilon$ круг. Про які предмети ви подумали?»

Важливо не забувати про аргументацію, спонукати дітей вчитися пояснювати, чому вони обрали саме той предмет. Наймолодшим потрібно спочатку дати змогу попередньо вивчити форму предметів, а під час гри пропонувати зорові підказки предметні картинки (дидактична гра «На що це схоже?»). Слід заохочувати малюків призами. Ці ігри стимулюють мовленнєву активність, роблять дітей сміливішими, формують уміння аргументувати власну точку зору. Працюючи з формами, варто обирати для себе одну форму і працювати 3 нею упродовж дня або тижня. Доречно намагатися помічати в довкіллі всі предмети, що мають визначену форму (прийом роботи - дидактична іграшка «Уважний фотоапарат», який фіксує у приміщенні та на прогулянці предмети відповідної форми).

4. Тактильні асоціації. Для цього виду роботи потрібно мати набір тактильних картинок, які запропонував професор, доктор педагогічних наук Ігор Матюгін. Основна ідея цих карток полягає в тому, що кожна з них має свою фактуру: хутро, наждачний папір, фланель, мотузка, палички, крапельки воску, велюр... До колекції можна додати картку з гудзиками, гречкою, шматками дроту, 3 дерматиновим покриттям. Принципи роботи залишаються такі ж, як і в попередніх видах роботи: «Про що ти подумав, доторкнувшись до цієї картинки?» (Я подумав про зайчика, тому що він пухнастий...)

Можна також пограти навпаки: пропонувати дітям дібрати до конкретного предмету зображення свої варіанти карток, відчуття від яких у них асоціюються із заданим предметом. Тоді запитання звучатиме так:

«У мене $є$ машина. Про яку картку ви подумали?»

На цьому етапі використовується авторський посібник «Тактильний будиночок»: дерев'яна модель будинку на два поверхи 3 горищем. У кожній 3 п'яти кімнат будинку знаходиться двостороннє дерев'яне ліжко, поверхні якого мають різну фактуру. Доторкнувшись до поверхні, діти уявляють, хто б міг спати на такому ліжку.
5. Предметні асоціації. Цей вид асоціації передбачає встановлення зв'язків предметів або між собою, або з їхніми ознаками. Для використання цього прийому вам стане у нагоді дидактична гра «Торбина несподіванок»: цікава торбинка з набором різних предметів (ниточка, паличка, трубочка, папірець, шматок тканини, шишка, каштан, камінчик, мушля, монетка, гудзик). Педагог бере нитку і говорить: «Довге і гнучке. Про що ви подумали?». Або тримати монетку і говорити: «Кругле і залізне». Про що ви подумали? (банка, іiї закривають кришкою).

6. Звукові асоціації. В ейдетиці застосовуються аудіозаписи різних звуків і шумів. Можна створити цілу колекцію звуків, розподіливши за різними групами: побутові шуми, звуки природи, музичні звуки, звуки вулиці тощо. $€$ також інший спосіб використання звуків. Потрібно зробити мішечки і покласти в них різноманітні предмети, що породжують звуки. Наприклад: в один мішечок покладіть папір, в другий - монети, в інші - коробочку з пластмасовими кульками, камінцями, квасолею тощо. Ставимо перед дитиною на набірному полотні ряд предметних зображень (книжка, цибуля, їжак, листок) і за допомогою звукового мішечка 3 целофановим папером пропонуємо обраний звук, після чого запитуємо: «Про що ти подумав, почувши цей звук?» (Я подумав про книжку, тому щзо коли ї̈ гортають, сторінки шурхотять). Не варто відгадувати, що міститься у мішечках, важливо створювати асоціативні образи за звуком.

7. Смакові асоціації. Мабуть, не знайдеться жодного педагога, який би не грав 3 дітьми у гру «Відгадай на смак». Але ейдетичний напрям не передбачає вгадувати предмет, тому пропонуємо авторські ігри «Спогади старого кухаря» (діти допомагають старому забудькуватому кухарю пригадати складники певної страви), «Кмітливий офіціант» (дитина-офіціант має уявити бажане замовлення гостей і принести його). Запитання буде таке ж, як раніше: «Про що ви подумали?» Для дітей старшого віку можна використовувати комбінації «солодке i гаряче», «солоне і холодне». За бажанням можна дати ще тактильно-смакові відчуття: хрумкий, соковитий, твердий, рідкий тощо.

Нюхові асоціації. Нюховий аналізатор - це, мабуть, найменший з усіх названих. Тому, залучивши його до роботи з малюками, потрібно 
бути особливо обережним, оскільки здатність сприймати різні аромати ще не достатньо вивчена. Можна використовувати нюхові коробочки з різними ароматами: парфумів, м'ятним ароматом, ароматів трав, спецій (ігри «Сад прекрасних ароматів і не тільки», «Вередливий носик»).

8. В ейдетиці використовуються і графічні асоціації. Для розвитку асоціативного мислення використовують друдли. Друдли (doodle + riddle (riddle - загадка, doodle-абстрактні каракулі) - це загадка-головоломка; малюнок, про який неможливо чітко сказати, що це таке. Так, круг діти можуть перетворити на сонечко, квіточку, яблуко, окуляри. Друдли знадобляться під час будь-якої гри-заняття. Наприклад: допоможуть пригадати тварин, овочі, фрукти, транспорт, рослини та інші. Під час показу друдла варто повертати його під різними кутами, щоб діти побачили якомога більше ракурсів цього зображення, щоб використати більше резервів обраного друдла. Використання друдлів сприяє розвитку асоціативного та дивергентного мислення, пам'яті, вчить знаходити нестандартні підходи до різноманітних завдань.

Використання цих та інших прийомів ейдетики у щоденній роботі корекційного педагога $\epsilon$ надзвичайно ефективним та цікавим способом саморозвитку та формування мислення, пам'яті, мовлення, креативності у дітей.
Висновки i перспективи подальших досліджень. У результаті використання прийомів ейдотехніки на корекційних заняттях маємо розвиток мовної компетентності, розширення активного словника дітей на основі тих відчуттів і вражень, які вони отримують під час виконання ейдетичних завдань. Мовлення стає барвистим, насиченим несподіваними образами та порівняннями. I основне - розповідь оживає, позбувається абстрактності, стає близькою і зрозумілою. Дитина вчиться знаходити несподівані образи у давно відомих предметах, надовго утримувати їх у пам'яті завдяки смішним історіям. На дієвість такого методу вказував К. Ушинський: «Учіть дитину п’ятьох слів, і вона довго буде мучитися над ними, а зв'яжіть двадцять таких слів із картинкою, і дитина запам'ятає їх блискуче» [7].

Ейдетика має велике значення в розумовому, фізичному, моральному й естетичному вихованні дітей, а також позитивно впливає на здоров'я. Наш досвід показує, що ігри з використанням прийомів ейдотехніки можуть застосовуватися в різноманітних формах:

- проводитися як самостійні;

- як такі, що випереджають або закріплюють знання дітей;

- активний відпочинок малюків;

- своєрідні «домашні завдання», які вимагають обов'язкової участі батьків.

ЛІТЕРАТУРА:

1. Антощук Є. Учімося запам’ятовувати і пригадувати. Київ : Вирій. 2007. С. 156-158.

2. Антощук Є. Українська школа ейдетики. Психолог. 2015. № 21/22. С. 4-9.

3. Брушневська I. Розвиток мовлення дітей старшого дошкільного віку 3 фонетико-фонематичним недорозвиненням мовлення засобами ейдетики. Запоріжжя :ТОВ «ЛІПС»ЛТД. 2014p. 102 с.

4. Великий тлумачний словник сучасної української мови / укл. В. Бусел. Київ : Перун, 2004. 1426 с.

5. Матюгин И. Эффективная память. Москва : РИПОЛ классик, 2005. 544 с.

6. Пащенко О. Ейдетика - що це? Дошкільне виховання. 2008, № 11 С. 16-17.

\section{REFERENCES:}

1. Antoshchuk Ye. (2007). Uchimosia zapamiatovuvaty i pryhaduvaty. kompleks [We learn to remember and recall]. Kyiv : Vyrii. C. 156-158. (in Ukrainian).

2. Antoshchuk Ye. (2015). Ukrainska shkola eidetyky. [Ukrainian School of Eidetics]. Psykholoh. № 21/22. S. 4-9. (in Ukrainian).

3. Brushnevska I. (2014). Rozvytok movlennia ditei starshoho doshkilnoho viku z fonetyko-fonematychnym nedorozvynenniam movlennia zasobamy eidetyky.[ Speech development of older preschool children with phonetic and phonemic underdevelopment of speech by means of eidetics]. Zaporizhzhia :TOV «LIPS»LTD. 102s. (in Ukrainian).

4. Velykyi tlumachnyi slovnyk suchasnoi ukrainskoi movy.( 2004) [Large explanatory dictionary of the modern Ukrainian language] / ukl. V. Busel. K. : Perun, 1426 s. (in Ukrainian).

5. Matiuhyn Y. (2005). Эffektyvnaia pamiat [ Effective memory] M. : RYPOL klassyk. 544 s. (in Russian).

6. Pashchenko O.( 2008). Eidetyka - shcho tse? [Eidetics - what is it]. Doshkilne vykhovannia., № 11. S. 16-17. (in Ukrainian). 